\title{
ITGA6 wt Allele
}

National Cancer Institute

\section{Source}

National Cancer Institute. IT GA6 wt Allele. NCI Thesaurus. Code C122060.

Human IT GA6 wild-type allele is located in the vicinity of 2 q31.1 and is approximately 79 $\mathrm{kb}$ in length. This allele, which encodes integ rin alpha- 6 protein, is involved in cell-matrix adhesion. Mutation of the gene is associated with epidermolysis bullosa with pyloric atresia. 